\author{
О.Н. Уваров \\ К ВОПРОСУ ОБ ИСПОЛНЕНИИ НАКАЗАНИЙ \\ В ВИДЕ ОБЯЗАТЕЛЬНЫХ И ИСПРАВИТЕЛЬНЫХ РАБОТ \\ В СЛУЧАЕ НАСТУПЛЕНИЯ У ОСУЖДЕННОГО \\ ПСИХИЧЕСКОГО РАССТРОЙСТВА ЛИБО ИНОЙ ТЯЖЕЛОЙ БОЛЕЗНИ, \\ ПРЕПЯТСТВУЮЩИХ ИХ ОТБЫВАНИЮ
}

\begin{abstract}
Решение вопроса об исполнении наказания в случае наступления у осужденного психического расстройства или иной тяжелой болезни, препятствующей его отбыванию, регламентировано ч. 5 и 6 ст. 175 УИК РФ, где прямо указано на то, что такой осужденный вправе обратиться в суд с ходатайством об освобождении от наказания, при этом, в соответствии с ч. 1 и 2 ст. 81 УК РФ, этот осужденный, в определенных случаях, освобождается судом от дальнейшего его отбывания. В свою очередь, ч. 8 ст. 175 УИК РФ определяет, что подача ходатайства об освобождении по приведенным основаниям возможна после медицинского освидетельствования осужденного и обнаружения у него заболевания, входящего в специальный перечень.
\end{abstract}

Ключевые слова: осужденные, освобождение от отбывания наказания по болезни, обязательные работыл, исправительные работы.

Решение вопроса об исполнении наказания в случае наступления у осужденного психического расстройства или иной тяжелой болезни, препятствующей его отбыванию, регламентировано ч. 5 и 6 ст. 175 УИК РФ, где прямо указано на то, что такой осужденный вправе обратиться в суд с ходатайством об освобождении от наказания, при этом, в соответствии с ч. 1 и 2 ст. 81 УК РФ, этот осужденный, в определенных случаях, освобождается судом от дальнейшего его отбывания. В свою очередь, ч. 8 ст. 175 УИК РФ определяет, что подача ходатайства об освобождении по приведенным основаниям возможна после медицинского освидетельствования осужденного и обнаружения у него заболевания, входящего в специальный перечень. Правила медицинского освидетельствования осужденных, представляемых к освобождению от отбывания наказания в связи с болезнью, и перечень таких болезней утверждены Постановлением Правительства РФ от 6 февраля 2004 г. № 54.

Таким образом, решение вопроса об освобождении осужденных в случае наступления у них психического расстройства или иной тяжелой болезни, препятствующих отбыванию назначенных им наказаний, представляется вполне определенно реализуемым отмеченным выше порядком. Вместе с тем, если приведенный вывод справедлив для осужденных к лишению свободы, то в отношении осужденных к наказаниям, не связанным с изоляцией от общества, такой подход вызывает некоторые сомнения.

Следует отметить, что, например, осужденные к наказаниям в виде запрета занимать определенные должности или заниматься определенной деятельностью и ограничения свободы, в связи с возникшей тяжелой болезнью, в соответствии со ст. 175 УИК РФ не освобождаются. Кроме того, при более вни- мательном рассмотрении становится очевидным, что Постановление Правительства РФ от 6 февраля 2004 г. № 54 «О медицинском освидетельствовании осужденных, представляемых к освобождению от отбывания наказания в связи с болезнью», ориентировано, в первую очередь, на определение возможности осужденного по состоянию здоровья находиться в местах лишения свободы и не делает акцента на оценку возможности либо невозможности выполнения осужденным определенной физической работы. Однако в случаях с исправительными либо обязательными работами, в отличие от лишения свободы, значима оценка именно возможности выполнения осужденным определенного ее вида и объема, так как общеизвестно, что эти наказания непосредственно связаны с выполнением осужденным соответствующего объема такой работы.

В рассматриваемом аспекте ч. 3 ст. 26 УИК РФ и ч. 4 ст. 42 УИК РФ, определяющие случаи, когда тяжелая болезнь возникает у осужденного к обязательным либо соответственно исправительным работам и становится препятствием для их отбывания, относятся к специальным нормам, регулирующим лишь строго определенные случаи. При этом следует подчеркнуть, что ст. 81 УК РФ не требует избирательности при своем применении в ходе исполнения лишения свободы, обязательных либо исправительных работ, действие же ч. 5, 6 и 8 ст. 175 УИК РФ все же скорректировано для обязательных или исправительных работ соответствующими специальными нормами, а, следовательно, их исполнение в случае тяжелой болезни осужденного к этим видам наказания осуществляется в соответствии с последними. Таким образом, право на обращение в суд с ходатайством об освобождении от дальнейшего отбывания наказания появляется у осужденного к обязательным либо исправитель- 
ным работам в случаях возникновения тяжелой болезни, препятствующей отбыванию наказания, отличных от случаев с осужденными к лишению свободы.

Для осужденного, как к обязательным, так и к исправительным работам, основным условием назначения, исполнения, а также отбывания наказания рассматривается его трудоспособность, следовательно, препятствие к его отбыванию может быть выражено лишь нетрудоспособностью последнего, а точнее, степенью такой нетрудоспособности. Нетрудоспособность - это такое состояние организма, обусловленное болезнью, травмой, ее последствиями или другими причинами, когда выполнение осужденным профессионального труда частично либо полностью, в течение ограниченного времени или постоянно невозможно. Нетрудоспособность, как минимум, подразделяется на полную, стойкую и временную. Полная нетрудоспособность - это полная невозможность выполнения любого труда, которая сопровождается необходимостью создания специального режима и проведения лечения (в нашем случае для осужденного - это признание его инвалидом первой группы). Стойкая нетрудоспособность, как постоянная (длительная), частичная (полная) потеря трудоспособности, в любом случае влечет за собой признание осужденного инвалидом. При этом установление инвалидности, в том числе определение ее сроков и степени утраты осужденным трудоспособности, осуществляется федеральными учреждениями медико-социальной экспертизы с использованием утвержденных классификаций и критериев. На их основании имеющий вторую группу инвалидности осужденный способен к выполнению трудовой деятельности лишь в специально созданных условиях с использованием вспомогательных технических средств, а осужденный с третьей группой - к выполнению трудовой деятельности в обычных условиях труда при снижении квалификации, тяжести, напряженности и (или) уменьшении объема работы.

Таким образом, наличие у осужденного инвалидности второй или третьей группы (а в возрасте до 18 лет - отнесение его к категории «ребенокинвалид») должно рассматриваться при ограничении трудоспособности как обусловленное болезнью, препятствующей отбыванию обязательных либо исправительных работ. В этих обстоятельствах уголовно-исполнительной инспекции необходимо выяснить в учреждении медико-социальной экспертизы, в чем конкретно выражается ограничение трудоспособности осужденного и способен ли он выполнять тот объем трудовой функции и в тех условиях, которые предусмотрены соответствующим наказанием. При этом лишь в случае объективной неспособности осужденного отбывать обязательные либо исправительные работы соответственно уголовно-исполнительная инспекция принимает меры к организации обращения в суд по существу вопроса об освобождении такого осужденного от дальнейшего отбывания наказания в связи с болезнью. В любом случае осужденному должно быть разъяснено право на обращение в суд с этим вопросом самостоятельно.

Говоря о временной нетрудоспособности, необходимо учитывать, что она обусловлена невозможностью выполнения профессионального труда в обычных производственных условиях в течение определенного промежутка времени (не отнесенного к длительному). Документом, подтверждающим временную нетрудоспособность, является листок временной нетрудоспособности. При амбулаторном лечении заболеваний (травм), отравлений и иных состояний, связанных с временной потерей трудоспособности, листки нетрудоспособности сроком до 15 календарных дней включительно выдает единолично лечащий врач. При сроках временной нетрудоспособности, превышающих 15 календарных дней, листок нетрудоспособности выдается и продлевается по решению врачебной комиссии, назначаемой руководителем медицинской организации. По решению врачебной комиссии листок нетрудоспособности может быть выдан на срок не более 10 месяцев, а в отдельных случаях (травмы, состояния после реконструктивных операций, туберкулез) - на срок не более 12 месяцев. Учитывая приведенные обстоятельства, помимо инвалидности второй и третьей группы, к препятствиям для отбывания наказания в виде обязательных либо исправительных работ должны быть отнесены заболевания, в связи с которыми листок нетрудоспособности выдается и продлевается по решению врачебной комиссии (т.е. при сроках временной нетрудоспособности, превышающих 15 календарных дней). Нетрудоспособность сроком до 15 дней (включительно) не может рассматриваться как препятствующая отбыванию таких наказаний и должна учитываться лишь как основание временного (на период действия листка нетрудоспособности) приостановления их отбывания. В таких случаях уголовно-исполнительная инспекция обязана убедиться в подлинности представленного осужденным листка нетрудоспособности, установление же иных обстоятельств его выдачи не является в данном случае обязательным. 


\section{ON PUNISHMENT EXECUTION IN THE FORM OF COMPULSORY COMMUNITY SERVICE AND CORRECTIONAL LABOUR IN THE EVENT THE CONVICT DEVELOPS A MENTAL DISORDER OR ANOTHER SERIOUS DISEASE THAT PREVENTS SERVING THE SENTENCE}

Ugolovnaya yustitsiya - Russian Journal of Criminal Law, 2016, 2(8), 78-80. DOI 10.17223/23088451/8/12

Oleg N. Uvarov, Corrective Services of the RF Federal Penitentiary Service in Tomsk Oblast (Tomsk, Russian Federation). E-mail: crimjust@mail.ru

Keywords: convicts, exemption from serving a sentence in the event of a disease, compulsory community service, correctional labour.

A Group II or III disability of the convict (a "disabled child" qualification for minors) should be considered as a result of a disease that prevents serving their sentence in the form of compulsory community service or correctional labour. In these circumstances, penitentiary inspectorates need to contact a medical and social expertise institution to clarify what the convict's incapacity to work consists in, and whether they are able to work in the volume and under conditions provided for by their punishment. In case the convict is objectively unable to do compulsory or correctional work, the penitentiary inspectorate takes measures to organise an appeal to the court on the merits of the issue of releasing the convicted person from further serving a sentence on the grounds of their disease. In any case, the convicted person must be explained the right to apply to the court with this matter on their own. Speaking about temporary incapacity for work, it is necessary to take into account that it is caused by the impossibility to perform professional work in usual working conditions for a certain period of time (not referred to as a longterm one). The document proving temporary incapacity for work is a temporary incapacity certificate. For outpatient treatment of diseases (injuries), poisonings and other conditions associated with temporary disability, incapacity certificates for up to 15 calendar days inclusive are issued by the physician. If the period of temporary incapacity for work exceeds 15 calendar days, the incapacity certificate is issued and prolonged by the decision of a medical commission appointed by the head of a medical organisation. By the decision of the medical commission, the incapacity certificate can be issued for a period of up to 10 months, and in some cases (trauma, condition after reconstructive surgery, tuberculosis) up to 12 months. Taking into account the circumstances mentioned above, in addition to Group II and III disabilities, factors that prevent serving the sentence in the form of compulsory community service or correctional labour should include diseases for which incapacity certificates are issued and prolonged by the decision of a medical commission (when temporary incapacity for work exceeds 15 calendar days). Incapacity for work for up to 15 days (inclusive) cannot be considered as a prevention for serving such sentences and should be taken into account only as the basis for temporary (for the period of the incapacity certificate validity) suspension of their serving. In such cases, the penitentiary inspectorate is obliged to verify the authenticity of the incapacity certificate the convict has; the establishment of other circumstances of its issuance is not mandatory in this case. 